\title{
C1GALT1C1 Gene
}

National Cancer Institute

\section{Source}

National Cancer Institute. C1GALT1C1 Gene. NCI Thesaurus. Code C112157.

This gene plays a role as a chaperone in generation of the common core $1 \mathrm{O}$-glycan structure. 